\title{
The Confluence in the Contemporary Art World of Literature and Postmodern Visual Arts in Jeff Vande Zande's Landscape with Fragmented Figures
}

\author{
Smriti Thakur ${ }^{1} \&$ Dinesh Babu $\mathrm{P}^{2}$ \\ ${ }^{1}$ Ph. D Research Scholar, Department of English, Central University of Punjab, E-mail: \\ mriti.thakur7@gmail.com \\ ${ }^{2}$ Assistant Professor of English, Centre for Classical and Modern Languages, School of \\ Languages, Literature and Culture, Central University of Punjab, E-mail: \\ dinesh.babu@cup.edu.in
}

\begin{abstract}
The American poet, novelist and editor, Jeff Vande Zande's Landscape with Fragmented Figures (2009) is a novel that deals with the contemporary world of art, which brings forth the intricacies of the art forms such as collage, action paintings, and drop cloths that have established a crucial distance between the present and the past world of pre-modern art. As the novel revolves around the world of postmodern visual arts and brings this subject into the literary world, it necessitates an interdisciplinary approach, which not only brings the two different academic disciplines of arts together for a critical appreciation, but also creates a new aesthetic experience in the reader, wherein visual arts is seen through the lens of literature, which helps foreground the hidden patterns and motives behind the art work, and the literary work is appreciated with a greater knowledge and understanding of the practices in and theories of the modern and postmodern art. By looking at the symbiotic relationship between visual art and literature through the novel, this study makes an attempt to contribute to the aesthetic appreciation of the engaging confluence of postmodern visual arts and literature in the contemporary world of art. By analysing the text, the study explores the phenomena that have reduced the difference between the original and copy in the contemporary art-world wherein the artist's aesthetic sensibility seems to derive from other sources, and thus brings into critical discourse those factors that have determined the use of parody, pastiche, irony, and collage in contemporary art forms.
\end{abstract}

Keywords: Modern-art, Postmodern-art, Visual-arts, art-novel, Aesthetic sensibility, Symbiotic relationship, Parody, Pastiche, Irony, Art Culture.

The American poet, novelist and editor, Jeff Vande Zande's Landscape with Fragmented Figures (2009) is a novel that deals with the postmodern visual arts, which revolves around the contemporary world of art. Commonly known as 'ekphrasis,' the description of visual arts in literature, and literature in visual arts, dates back to the time when the energetic quality of oral literature and the cave paintings of the Paleolithic era were believed to serve the audiences by evoking the vivid imageries in their minds' eye. Simonides, a Greek lyric poet, claimed that "painting was silent poetry and poetry a speaking picture, Himerius believed that words could

(c) AesthetixMS 2020. This Open Access article is published under a Creative Commons Attribution Non-Commercial 4.o International License (http://creativecommons.org/licenses/by-nc/4.o/), which permits non-commercial re-use, distribution, and reproduction in any medium, provided the original work is properly cited. For citation use the DOI. For commercial re-use, please contact editor@rupkatha.com. 
draw designs which made ears serve for eyes" (Chaffee, 1984). And ages demonstrated that Literature and Visual arts as forms of human expression have been silently collaborated, converged, and slip into one another in several ways. Sometimes it is in the context of social concerns, and practices, and other times in the conscious working patterns where artistic identities of two or more artists find deserving and equal space during the collaboration. John Keats' metaphorical description of Urn in "Ode on a Grecian Urn," Salvador Dali's 1969's interpretation of Lewis Carroll's novel Alice in Wonderland (1865), the American artist, Matt Kish's drawings of Herman Melville's Moby-Dick, the project of Agrippa collaborated by both fiction writer William Gibson and the painter Dennis Ashbaugh, and a number of art novels such as Kurt Vonnegut's Bluebeard (1987), Chaim Potok's My Name is Asher Lev (1972), and The Gift of Asher Lev (1990), Jane Urquhart's The Underpainter (1997), and so on, are such instances in the history of the art world that prove that fusion and confluence of creative mediums have done much to elevate one's visual and aesthetic sensibilities. As these artistic creations not only give one the taste of two artistic disciplines in one platform but the resulted art objects seem like an offspring of two different art languages where one can sense the aesthetic and emotional effect of the two sipping from one cup. And it is this cross-disciplinary approach of the contemporary art world that has played a poignant role in making arts a vital part of global culture as it enables the people of different cultures, and times, to connect with each other via images and words. In the same way, Jeff Vande Zande's Landscape with Fragmented Figures (2009) is one such illustration in the present art world, wherein literature gives verbal description to the visuals of paintings and has come and engaged together to reflect the present social concerns.

When the success of abstract expressionist art was at its peak and had got mainstream acceptance in the 1950s, Andy Warhol, who introduced the concept of "Pop-art," celebrated the low and mundane products of popular culture and also redefined art as "anything that we call art, removing the aura of specialness and spreading out the definition of art to apply to almost anything" (Hagman, 2010). By portraying ordinary items as the masterpieces, he sabotaged the elements of modern aesthetics and elevated the common and the so-called vulgar into fine art pieces. The same play with aesthetics is illustrated in Landscape with Fragmented Figures, wherein the character Claude Kleminger asks: "A single dot in the middle of a canvas. Is it art?" (Zande, 2009). The very reference to the 'single dot' here actually represents the focused attention of an artist which seems to indicate that art has no easy definition in the era of postmodernism. And, it also points toward the significance of a dot in the visual arts which brought line, plane, and shape into motion. At the same time, it throws light on how contemporary artists see themselves as a part of an infinitely complex global community in which innovation and experimentation are the norms. What seems significant to the newer generation of artists is the variety of their art forms and techniques and their experimentation with it. The same spirit of experimentation and playfulness of postmodern artists and an inventive influence of modernism in the postmodern era is quite evident in the novel, wherein the artists have not only been depicted as being mesmerised by the works of their immediate predecessors such as Jackson Pollock, Diego Rivera, and Hopper but have been seen to extend the boundaries of aesthetics where things like drop cloth find space in the art galleries: "The drop cloths and photographs were now hanging in a gallery in Ann Arbor" (Zande, 2009).

Known for their mischievous aesthetic approach, they have considered a cross-disciplinary approach, photography, video, or the filming of mundane scenes, an important aspect of the artistic process. Expressions of pure subjectivity, raw sensuousness, and the personal vision of self, have no significance to them as depicted in the creative process the female character Chloe 
follows in the novel. She says, "I mounted a video camera on my dashboard. When I made long trips, I filmed myself driving" (Zande, 2009). This self-conscious use of electronic devices, which focuses more on the surface appearances of things, indicates the complex nature of contemporary art, where the depiction of each image shows advancement in the previous images. As exposited in the series of road paintings Chloe has made from the video recordings, which she shows to Raymond Casper for critical reviews:

Though similar in theme, each painting was different. Some of the cars had a lone driver, some had a driver and a passenger, some had a man, a woman, and a child in the back seat. Others were from the opposite perspective, as though Chloe were sitting in the back seat while she painted. (Zande, 2009)

It is quite apparent here how the paintings of Chloe show a succession on previous paintings by fusing fantasy and reality in it. Moreover, these paintings of her make a statement as to how each thing refers to another thing and make a chain of the never-ending cycle which makes it impossible for one to set the hierarchy of values in the postmodern world.

For the postmodern artists, art is not necessarily a vehicle for depicting the self or the autobiographical details of the life of the artists, but a medium to explore the multiple layers of meaning that control human activities in this fast-growing world of economy, which is possible to uncover only through parody, pastiche, irony, and collage, as employed in the artistic creations of postmodernists in the novel like Kleminger, Przybylski, Raymond Casper, Diane, and Chloe. Here, in Landscape with Fragmented Figures, Zande not only parodies and eschews the modernist quest for meaning in the present chaotic world through his narration, but celebrates putting the socalled low and high art forms on the same line by portraying the elements of postmodernism through the artworks and characters of Przybylski, Kleminger, Chloe, and Diane.

By shattering the old conceptions of aesthetics, postmodernists have altered the psychological functions of art and have challenged the common assumptions about the creative process and the artist's relationship with his works of art. As a result of this, innovation and productivity have stimulated across the world of art. This evolving process of post-modernity is quite evident in the novel wherein the characters like Raymond Casper, Diane, Chloe, and Kleminger are seen experimenting with their art forms. Here, art is not just depicted as an institution but represented as an evolving complex human phenomenon that is less specific in nature, and encompasses various methods, mediums, and forms, that articulates the varied aspects of human experiences and subjectivity. This is apparent in the case of the character Diane's artistic work titled Spontaneous Splatter: the Art of the Working class.

She took photographs of the painters themselves - men with speckled mustaches and ruddy skin [... . She's stretched the drop cloths over large frames she'd made [... .] She'd captured each man, something about his essence. (Zande, 2009)

This artwork of Diane explains the postmodern phenomena wherein there is no longer any difference between original and copy remains. By sticking and stretching the photographs and drop clothes of different artists on the large canvases in a collage form Diane seems to make a statement that the postmodern era is the age of 'Mini narratives' where an artist's aesthetic sensibility derives from other sources. 
By representing the artworks of the characters such as Raymond Casper, Diane, Claude Kleminger, and Chloe in the novel, Zande throws light on those artistic forms such as action paintings and collage that have permanently established a distance between the present and the distant world of pre-modern art. For instance, in the artwork of Raymond Casper titled Pollock's Kinked Neck:

An action painting. The ceiling above him was still splattered with paint from the process. He had nailed canvases to the ceiling and flung paint upwards. Its dripping to dry had a nice effect. (Zande, 2009)

Rather being applied carefully, these spontaneous splatters on the canvases not only emphasise the outer and physical act of an artist but indicate towards the playfulness of the postmodern artists, who celebrate the sense of nothingness through their works of art. It also defines an attitude of skepticism, irony, and rejection of enlightened rationality, which has denied the possibility of reliable knowledge, stable reality, and the existence of the universal, which had been adored by the artists of the earlier generation. It is their will to objectify their aesthetic sensibilities by addressing the social issues of gender, identity, and discrimination through their works of art that has presently made their artistic attempts and creations a vital part of global culture.

Jeff Vande Zande's cross-disciplinary approach can be seen in the novel wherein he encompasses visual arts to represent the disillusionment of contemporary artists, whether they are painters, sculptors, or writers, who are feeling lost in this fast-growing world. By doing this, he represents the factors that have brought a shift in the world of contemporary art and also uses visual arts to depict the influencing power any work of art has in the society. Here, he gives equal space to the power of visuals along with his powerful narration of words that engages the readers beyond the differences between the two and makes them realise that the different forms and approaches of contemporary art have different reasons for being created.

When we looks at the depiction of artists in $20^{\text {th }}$ century literature, we notice that in the novels, which are set in the modern era such as My Name is Asher Lev, The Gift of Asher Lev, The Underpainter, Bluebeard, etc., the artists have been seen relying much on their memories while creating their artistic works, whereas in Landscape with Fragmented Figures, which is set in the postmodern era, the artists have been seen relying much on the technical equipment for their artistic creation. For instance, while discussing her new artworks with her ex-mentor Raymond Casper, Chloe tells him that "I have hours and hours of tape. People on country roads [...] There's a face people get when they're driving" (Zande, 2009). This shift of memory to technology not only indicates the break western aesthetics encounter as a result of the introduction of a camera on large scale during the 1950 s as it is mentioned in Jane Urquhart's The Underpainter, but also represents the reliance/dependency, present century has on the new inventions in technologies, which has also made art a participatory experience and has taken visual arts up to the point where no one can stop the works of art from reaching its audiences.

In this novel, Jeff Vande Zande, by framing the taste of the two artistic languages alongside, not only puts forth the interesting parallels and obvious differences between the two but also divides the knowledge of the two employing postmodern approaches. The literary description of postmodern artworks such as the sculpture of old furniture frames by the character Claude Kleminger, the artist-cum-art professor, and the sketches of businesswoman in man's suit 
by Chloe give not only a visual in Landscape with Fragmented Figures but a vision to the world through words:

The perspective of the painting was from the rear seat. The driver, a woman, leaned over into the mirror to apply makeup . . . she's in a business outfit . . . from the back how it almost looks like she's in a man's suit. ... That's the dashboard of a luxury car. . . A child's car seat. (Zande, 2009)

By portraying an image of a child's car seat in the painting, Chloe seems to suggest that women are entering the world of business but on the terms and conditions of men. They have not only forsaken their maternal essence but give men more power by following their terms, as evident in her act of applying makeup in the middle of traffic. For Chloe, the traits like compassion, empathy, and a woman's maternal nature are not weaknesses but her strength. She seems to suggest that in order to make its place or presence in this fast-moving world one should not overlook or compromise their individuality but instead make their talent equal to millions of bucks, so that no one can surpass your position in the society. On the other hand, Claude Kleminger's sculpture of furniture tries to beautify those objects or take them to parallel on the scales of beauty which were earlier never given consideration. And Zande, by illustrating how these artworks can influence society, makes it clear that when arts have been produced to reflect the power structures of society, it hits the audience/readers with the same intensity no matter what languages and forms they have.

Zande, while presenting the postmodern visual world through the novel, also warns the contemporary artist. It is through the portrayal of the character of Raymond Casper, the artistcum- art teacher in the novel, and the description of an unnamed novelist, who teaches in a big writing school of Iowa, that Zande warns the contemporary artists about what happens when one ignores one's artistic instincts. He says, what "she really wanted to do was [to] write about D. H. Lawrence and his frequent references to avian life. She felt trapped because the college had hired her as their expert in $19^{\text {th }}$ Century American Literature" (Zande, 2009). It is quite possible that Zande, who teaches writing at the Delta College, becomes autobiographical here. Nevertheless, he makes his point clear in the novel through the character of Claude by saying that: "Teaching, Raymond. Even if it takes time from our work, we have to take it seriously" (Zande, 2009). Here he conveys the idea that one has to find his way out nobly instead of surrendering one's talent completely, just like Casper, the protagonist, did in the novel. One should be intoxicated and possessed by the one idea s/he wants to express through his/her works of art. Here, Zande not only seems to address the present generation of writers but the artists of other art disciplines as well, because creation in whatever field always needs the undivided attention of the creator to generate the outcome and to continue the legacy their ancestors have left in their hands with a difference.

The contemporary world of visual arts, which the novel represents, is innovative, productive, collaborative, and experimentatory in nature, and which denies any dominant aesthetic style, medium or movement. Due to this, the style of postmodern visual arts is indefinable in nature. However, Jeff Vande Zande, while dealing with this theme in this novel, employs a narrative style which is neither experimentatory nor postmodern but linear and expository. This has helped the author to explain, elaborate and communicate in a convincing and appealing way the reasons behind the existence, development and application of the indefinable style in the postmodern visual arts. Zande here uses literature as a medium to frame the story of the transition of the world of visual arts from the modern to the postmodern in order to 
foreground the condition of the contemporary postmodern artists, who have not only sustained the heritage they have received from their predecessor by reproducing the artworks in their style, like the artistic creation of the character Casper in the novel, but also added up the liberated flights and experimental spirit of an individual's mind that gives birth to the new art forms such as Pop art, Installation art, Conceptual art, Performance art, Neo-Expressionism, Neo-Dada, Constructivism, and Action painting in the latter decades of twentieth-century America. Hence, Zande through this novel familiarises the readers in a symbiotic way the wonderful world of visual arts, and educates and enlightens them about the inevitability of the transition. At the same time, by dealing with this theme, the novel paves the way for an understanding and appreciation of the interconnections among different postmodern visual art forms and techniques and their experimentations with it, which may help enhance the appreciation of the contemporary literature as well. Nevertheless, this thematic fusion and artistic confluence of creative mediums, that we experience in the novel wherein artistic identities of many artists find deserving and equal space, and one art is being made from other arts, has definitely done much to elevate the visual and aesthetic sensibilities of the contemporary readers.

\section{References}

Chaffee, Diane. (1984). Visual Art in Literature: The Role of Time and Space in Ekphrastic Creation. Revista Canadiense de Estudios Hispánicos 8(3), 311-320.

Hagman, George. (2010). The Artist's Mind: A Psychoanalytical Perspective on Creativity, Modern Art and Modern Artists. Routledge.

Zande, Jeff Vande. (2009). Landscape with Fragmented Figures. Bottom Dog Press. 